\section{Post or Propter?}

The "colitic type" has been variously categorized" ${ }^{1-6}$ in psychological terms as depressed, dependent, passive, egocentric, intelligent, effeminate, immature, helpless, and hopeless. Attacks of ulcerative colitis or Crohn's disease are commonly said to be brought on by conflicts in which the patient is defeated or rejected emotionally; and indeed some workers even believe ${ }^{5}$ that emotional stress may initiate the colonic disease in the first place. Psychotherapy ${ }^{7}$ and even prefrontal leucotomy ${ }^{8}$ have been recommended.

Until recently the only evidence against this view had been that brought forward by practising clinicians ${ }^{9-12}$ who stoutly averred that their patients' collective psychological make-up approximated to that of the rest of the general population. But in the past few years two formal psychological surveys have been reported; and their results indicate that the role of emotional factors in the initiation of colonic inflammatory disease may well have been over-emphasized. F. Feldman and colleagues from Los Angeles ${ }^{13} 14$ investigated consecutive series of 34 patients with ulcerative colitis and 19 patients with regional ileitis, and found that the patients with colitis presented "essentially the usual distribution of emotional problems to be expected in a group of that size." The patients with regional ileitis showed "no evidence . . . that any emotional factor was a significant aetiological component." They cautiously questioned, indeed, whether the diseases should be regarded as psychosomatic in any way.

Since the numbers were small, the Los Angeles group's conclusions were naturally tentative. However, in a more recent study from Baltimore (158 patients with ulcerative colitis and 69 with Crohn's disease, as well as a representative sample of over 700 persons drawn from the general population) A. I. Mendeloff and his colleagues ${ }^{15}$ came to the same general conclusion. They studied events which were considered to be disruptive emotionally or psychologically, such as "social and cultural discontinuities" (by which they meant marrying someone with a different religious or educational background, moving home, changing employment, as well as other similar stressful events). The Baltimore group paid particular attention to the period immediately before admission to hospital, but they were unable to show any real differences between the control and colitic groups.

These two studies reflect a change in current opinion, in that a psychosomatic view of ulcerative colitis and Crohn's

\footnotetext{
1 Murray, C. D., American fournal of the Medical Sciences, 1930, 180, 239. Engel, G. L., American fournal of Medicine, 1955, 19, 231.

3 Paulley, J. W. Gastroenterology, 1950, 16, 566.

4 Edwards, H. C., Annals of the Royal College of Surgeons of England, 1969, 44, 121 .

Groen, J., and Van Der Valk, J. M., Gastroenterologia, 1956, 86, 591.

- Lepore, M. J., Fournal of the American Medical Association, 1965, 191, 819.

7 Psychosomatic Specificity, ed. F. Alexander, T. M. French, and G. H. Pollock, Volume I, p. 13. London, University of Chicago Press, 1968.

Bucaille, M., Scalpel, 1964, 117, 223.

Blackburn, G., Hadfield, G., and Hunt, A. H., St. Bartholomew's Hospital Reports, 1939, 72, 181 .

10 Crohn, B. B., and Yarnis, H., Regional Ileitis, 2nd ed., p. 28. New York, Grune and Stratton, 1958.

11 Bacon, H. E., Ulcerative Colitis, Philadelphia, Lippincott, 1958.

12 Goligher, J. C., de Dombal, F. T., Watts, J. McK., and Watkinson, G., Ulcerative Colitis, London, Bailliere Tindall and Cassell, 1968.

13 Feldman, F., Cantor, D., Soll, S., and Bachrach, W., British Medical Fournal, 1967, 3, 14.

14 Feldman, F., Cantor, D., Soll, S., and Bachrach, W., British Medical fournal, 1967, 4, 711.

15 Monk, M., Mendeloff, A. I., Siegel, C. I., and Lilienfeld, A., Fournal of Chronic Diseases, 1970, 22, 565.
}

disease is less widely held than was the case ten years ago. Any clinician will meet patients with colitis who are anxious and depressed-and who like other sick persons need reassurance and sympathy. But it does seem increasingly probable that this anxiety and depression is in most cases the result rather than the cause of the disease.

\section{Referendum on Resignation}

By the time this journal is in print most N.H.S. doctors will have filled in their referendum papers and, it is to be hoped, returned them to the British Medical Guild. The question asked was: "Are you prepared to withdraw from the National Health Service if the Government will not assure the continued existence of the independent Review Body, and the honouring of its awards in the terms defined by the Royal Commission, without reference to any other tribunal?"

There is no doubt that an overwhelming majority of the profession has had confidence in the review body system, and is angry that the Government has abused it. It would not be surprising therefore if the referendum showed that a large number of doctors would be prepared to withdraw from the N.H.S. on this matter of principle. If so, it will be a significant measure of their resentment, because, contrary to what has been said in some quarters, there is no evidence that doctors are "spoiling for a fight" or wanting to "wreck the Health Service." The opposite is the case.

Withdrawing from the Health Service is, as we said last week, ${ }^{1}$ something which will hurt the doctors but not the patients, and in a covering letter with the referendum form the British Medical Guild emphasizes that withdrawal of doctors from the N.H.S. need involve no interruption in the medical care of the community. There is nothing, it is pointed out, to stop doctors from practising outside the Service. Since this must mean in the case of general practitioners a return to private practice it raises the question of possible hardship to the poorer patients. But medicine is a humanitarian profession. In the days when fees from private practice represented most of a doctor's earnings medical men were noted for their compassion. There is no reason to suppose that doctors today would be different. And it is difficult to believe that, with its statutory responsibilities under N.H.S. Acts in mind, the Government would not feel bound to do something to assist people in paying their medical bills. Similarly, hospital doctors could expect to be paid for services they would continue to give, because the hospitals could not function without them.

But, if it comes to it, there will be time to discuss these matters. The ballot paper is not in itself a form of resignation and it does not commit the signatory. It is a way of obtaining an expression of collective opinion. Only after considering this opinion, and only if at least half of those voting state that they are prepared to withdraw, will the trustees of the Guild decide whether to consult the profession further about withdrawal of services from the N.H.S. A Special Representative Meeting at Harrogate on 27 June will consider the results of the referendum.

${ }^{1}$ British Medical fournal, 1970, 2, 615. 